\title{
Does drought stress always negatively affect the yield and quality of soybean in Hungary?
}

\author{
Oqba Basal - András Szabó \\ University of Debrecen, Faculty of Agricultural and Food Sciences and Environmental Management, \\ Institute of Crop Science, Debrecen \\ oqba@agr.unideb.hu
}

\begin{abstract}
SUMMARY
Globally-fluctuating climate imposed serious abiotic stresses on the agricultural sector, leading to noticeable, and sometimes disastrous, losses in yields and/or quality of crops; however, in certain cases, plants could survive stress with relatively low reductions, and sometimes even with some enhancements as a reaction to changed environment, especially in the case of mild stress. An experiment was conducted in 2017 and 2018 in Debrecen, Hungary to evaluate the mild drought stress influence on the yield and quality of three soybean cultivars. The results showed that both ES Pallador and Pedro cultivars could achieve more yield when subjected to mild drought conditions; however, protein concentration was enhanced in ES Pallador whereas slightly degraded in Pedro under drought. The cultivar Pannonia Kincse followed different trend; both yield and protein concentration were reduced under drought. Oil concentration of the three cultivars did not show significant changes; however, it always followed opposite trend to that of protein concentration. It could be concluded that both ES Pallador and Pedro are recommended to be grown under rain fed conditions in Debrecen, whereas Pannonia Kincse is recommended under irrigation conditions.
\end{abstract}

Keywords: drought stress, oil concentration, protein concentration, soybean, yield

\section{INTRODUCTION}

Climate prediction models show occurrences of drought, flooding, and high temperature periods during the crop vegetative periods increasingly (Mittler and Blumwald, 2010; De Paola et al., 2014), consequently, global food production will be kept under pressure; the demand for food and oil crops will keep increasing with the increase in global population. Therefore, it is vital to enhance crop productivity in order to ensure sustainable yields under the altered environmental conditions (Mutava et al., 2015). To do so, increasing understanding of plant responses to abiotic stresses is needed (Morison et al., 2008).

Water is considered as the main factor determining yield performance under drought. Drought usually negatively influences both quantity and quality traits of plants (Vurukonda et al., 2016). It has been reported, for many crops [e.g. wheat (Merah, 2001); rice (Kato et al., 2008); chickpea (Leport et al., 2006; Fang et al., 2010)], that crop yield mostly depends on water use during the reproductive stage. Irrigation is a strategy applied to overcome the negative effects of drought stress on crop yields, however, the available water resources are continuously declining, so there is a need for crop adaptation to water-limited environments and more efficiency of water use in order for more food per unit of water to be produced (Mutava et al., 2015). Some strategies might be useful to be applied in the field in order to overcome drought; for example, early sowing strategy can potentially lead the plants to avoid drought stress in the later summer months (Rosenzweig and Tubiello, 2007). On plant basis, mechanisms of plants in response to drought vary among species (Khan and Komatsu, 2016); they induce different physiological and biochemical changes which lead to disturbing normal growth and development (Reynolds and Tuberosa, 2008). On the other hand, drought stress activates defense mechanisms that function to increase drought tolerance (Yamaguchi-Shinozaki and Shinozaki, 2006); these mechanisms include stress signal induction which, in part, results in activating many physiological and metabolic responses (Valliyodan and Nguyen, 2006).

Soybean (Glycine max (L.) Merrill) is the world's fourth most important food crop; it provides about $60 \%$ of the total vegetable protein for human use (Allen et al., 2009), in addition to vegetable oil (Li et al., 2013). The composition ratios of soybean's both protein and oil are determinant to the interactions between the genotype and the environment (Fehr et al., 2003; Wilson, 2004).

\section{MATERIALS AND METHODS}

This experiment was conducted during 2017 and 2018 in Debrecen University's experimental site (Látókép) (N. latitude $47^{\circ} 33^{\prime}$, E. longitude $21^{\circ} 27^{\prime}$ ). The soil type is calcareous chernozem. Three soybean cultivars; Pannonia Kincse, ES Pallador and Pedro (middle maturity group) were sown under two irrigation regimes; rain fed regime, where the irrigation was solely dependent on the precipitation, representing the drought-stressed treatment (DT), and fully-irrigated regime, where irrigation was applied as a complement to precipitation, representing control treatment (CT). Average precipitation and irrigation amounts during the vegetative period of the plants (from April to the end of August) are illustrated in Figure 1, whereas the average temperatures are illustrated in Figure 2. Each treatment consisted of four replicates.

The statistical analysis (2-way ANOVA) was made using SPSS (ver.22) software. 


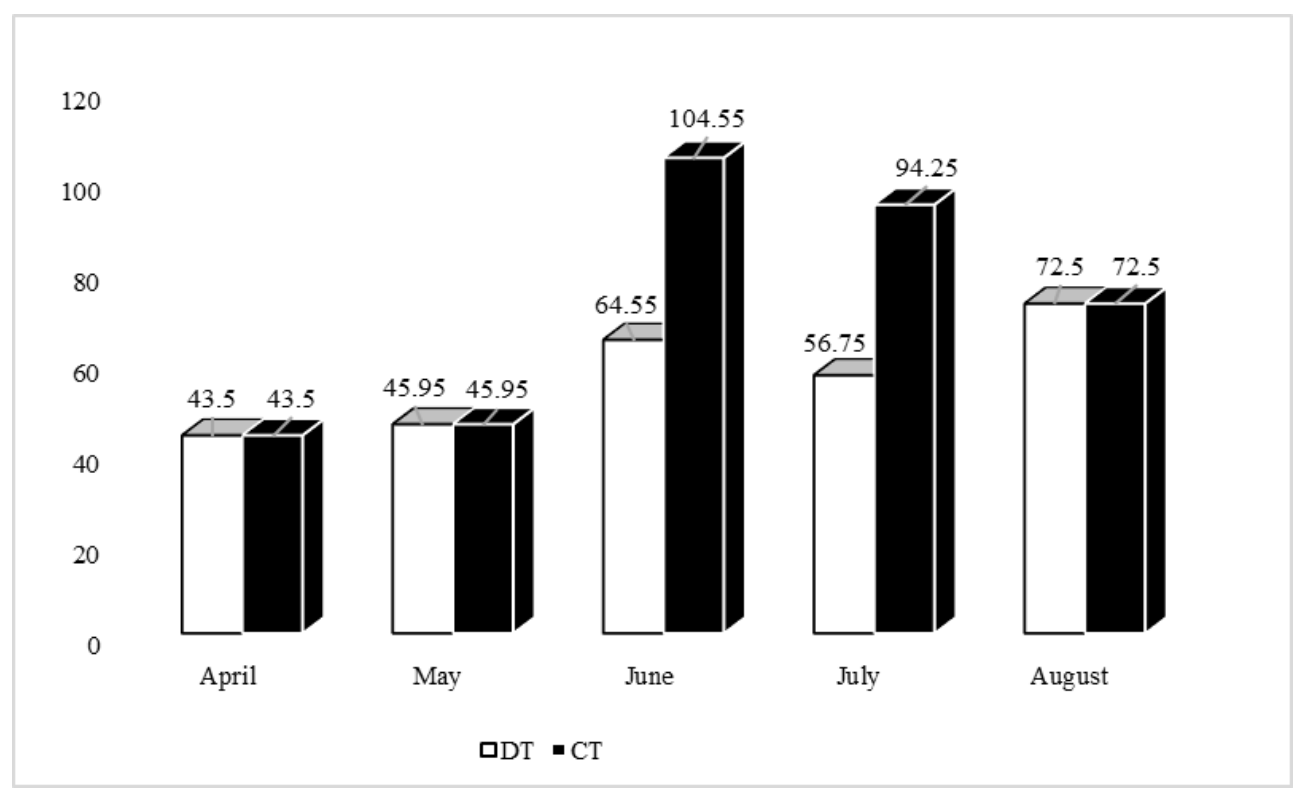

Figure 2: Average temperature $\left({ }^{\circ} \mathrm{C}\right)$ in 2017 and 2018 during the vegetative period of the plants

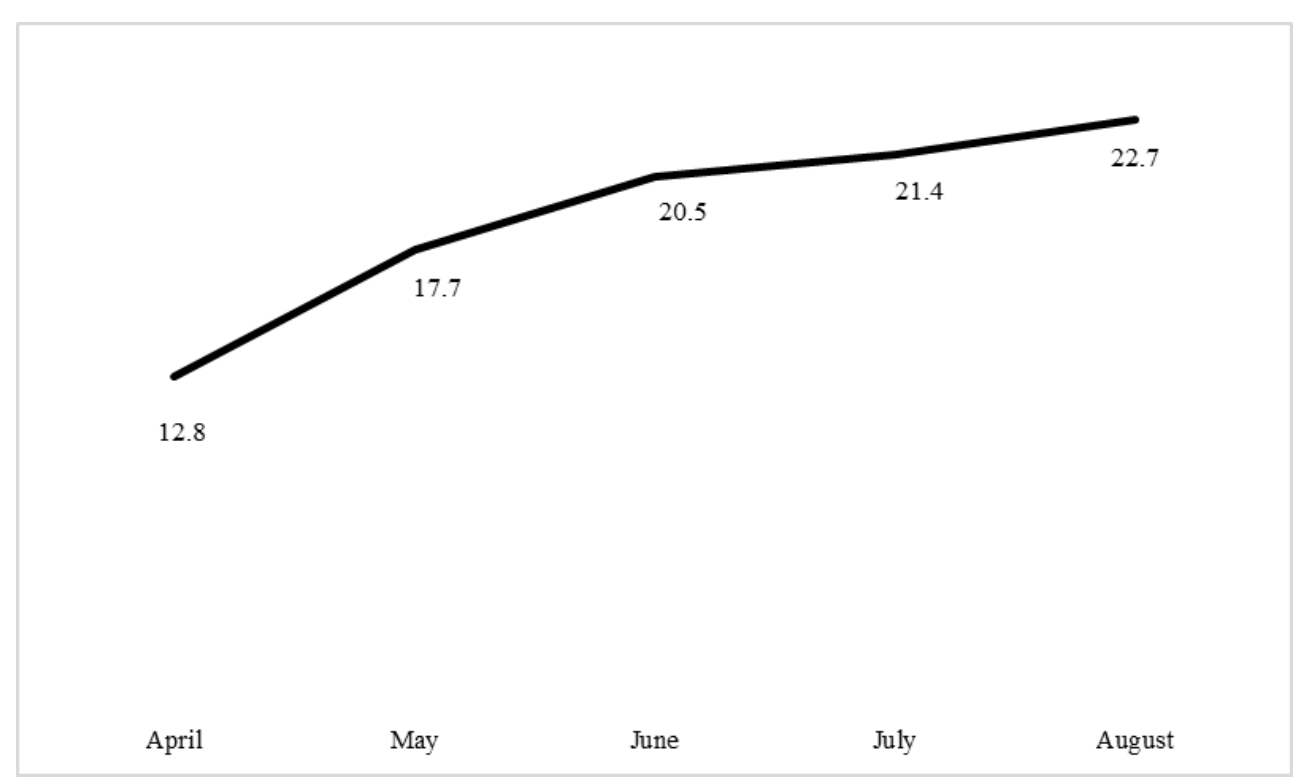

\section{RESULTS AND DISCUSSION}

\section{Yield $\left(\mathrm{kg} \mathrm{ha}^{-1}\right)$}

Irrigation resulted in reducing the yield of both $E S$ Pallador and Pedro (from 4470 to $3902 \mathrm{~kg} \mathrm{ha}^{-1}$, and from 4537 to $4092 \mathrm{~kg} \mathrm{ha}^{-1}$ for non-irrigated and fullyirrigated, respectively), moreover, the reduction was significant for both cultivars. However, irrigation insignificantly increased the yield of Pannonia kincse to $4172 \mathrm{~kg} \mathrm{ha}^{-1}$ (from $3978 \mathrm{~kg} \mathrm{ha}^{-1}$ of the non-irrigated counterpart) (Table 1). The negative effects of drought stress on soybean plants depend on the phenological stage (Avila et al., 2013; Ku et al., 2013); for example, drought influence on grain yield could be alleviated if it occurs at early vegetative stages, because plants will probably have time to recover, whereas drought at reproductive stages may result in noticeable reductions in yield (Chalk et al., 2010). In our study, drought occurred during the period between V4 and V6 stages, whereas plants did not suffer from serious water shortage during the reproductive stages (R1 to R8). Results by Song (1986) indicated that water stress during both pod setting and seed filling stages had the biggest influence on grain yield of soybean because of the reductions in both seed number and seed size; Xie et al. (1994) reported similar results.

From another point of view, the increased yield of Pannonia Kincse exceeded the other two cultivars' 
yield under fully-irrigated regime (CT), although the increase was not significant, whereas the same cultivar significantly yielded the least under non-irrigated regime (DT). Moreover, the yield of both ES Pallador and Pedro, under rain-fed conditions, was better than that of Pannonia Kincse even when the latter was fullyirrigated (Table 1), which may raise the conclusion that both cultivars are more convenient to be rainfed-sown under the current climatic conditions in Debrecen compared to Pannonia Kincse, even if the latter is irrigated.

\section{Protein Concentration (\%)}

Considerably different attitudes were revealed by the three cultivars; the protein concentration of ES Pallador dramatically dropped (from 36.4\%) when irrigated (to 34.7\%), however, the reduction was insignificant (Table 1). In some experiments where water stress was imposed early, seed protein content increased about 6\%; this increase was justified as a probable response to a seed number reduction. Although water stress shortens the duration of seed filling, which leads to reducing all component contents, yet protein synthesis is less affected because of the increased amino-N remobilization from leaves to seeds, resulting in a net increase in protein concentration in the mature seeds; in other words, remobilization in water stressed plants maybe enables protein accumulation to continue longer than oil and residual accumulation (Rotundo and Westgate, 2009).

The protein concentration of Pannonia Kincse, on the other hand, was significantly enhanced when irrigated, as its concentration recorded $38.5 \%$ (relative to $36.1 \%$ for the non-irrigated counterpart) (Table 1). Previously, Turner et al. (2005) reported a $24 \%$ decrease in seed protein content under stress conditions in chickpea plants; similar results were reported later on soybean by Rotundo and Westgate (2009) who demonstrated that water stress during the early reproductive stages resulted in a $16 \%$ decrease in seed protein. Though this trait was slightly better $(37.7 \%)$ for irrigated treatment of Pedro, yet the difference from the non-irrigated treatment $(37.2 \%)$ was insignificant and relatively low (Table 1$)$.

When comparing between the cultivars, Pedro could achieve the best protein concentration under rainfed conditions (in addition to the best yield as mentioned earlier), whereas Pannonia Kincse had the least protein concentration (in addition to the least achieved yield). However, the protein concentration of Pannonia Kincse was significantly the best when irrigation was applied (Table 1); this conclusion supports the preliminary recommendation of the preferability of sowing Pedro under rainfed conditions, whereas Pannonia Kincse would be the best choice for irrigated regime.

Yield $\left(\mathrm{kg} \mathrm{ha}^{-1}\right)$, protein and oil concentrations $(\%)$ of the three studied soybean cultivars under two irrigation regimes

\begin{tabular}{|c|c|c|c|c|}
\hline Trait & Irrigation Regime & ES Pallador & Pedro & Pannonia Kincse \\
\hline \multirow{2}{*}{ Yield } & DT & $4470^{a 1}$ & $4537^{\text {al }}$ & $3978^{\mathrm{a} 2}$ \\
\hline & CT & $3902^{b 1}$ & $4092^{\mathrm{b} 1}$ & $4172^{\mathrm{a} 1}$ \\
\hline \multirow{2}{*}{ Protein Concentration } & DT & $36.4^{\mathrm{a} 1}$ & $37.2^{\mathrm{a} 1}$ & $36.1^{\mathrm{b} 1}$ \\
\hline & CT & $34.7^{\mathrm{a} 2}$ & $37.7^{\mathrm{a} 2}$ & $38.5^{\mathrm{a} 1}$ \\
\hline \multirow{2}{*}{ Oil Concentration } & DT & $22.9^{\mathrm{a} 1}$ & $22.7^{\mathrm{a} 1}$ & $23.8^{\mathrm{a} 1}$ \\
\hline & $\mathrm{CT}$ & $23.0^{\mathrm{a} 1}$ & $22.2^{\mathrm{a} 1}$ & $22.7^{\mathrm{a} 1}$ \\
\hline
\end{tabular}

- The same letter indicates no significant difference at .05 level between the two irrigation regimes of certain genotype within the same trait.

- The same number indicates no significant difference at .05 level in a particular trait among the three genotypes within the same irrigation regime.

\section{Oil Concentration (\%)}

Both Pedro and Pannonia Kincse were lower, whereas ES Pallador was slightly higher in oil concentration when irrigation was applied; however, the differences were insignificant in all cultivars (Table 1). Results of some studies indicated that the drought stress reduced oil concentration in the seed (e.g. Bellaloui and Mengistu, 2008; Rotundo and Westgate, 2009), whereas few other reports showed increased oil concentration with the water deficit (e.g. Boydak et al., 2002). However, Gao et al. (2009) reported that drought stress had little effect on oil concentration. The timing of drought stress was concluded to have an important effect; the early-stage drought did not affect the oil concentration, whereas drought stress during seed filling stage resulted in a reduction of $35 \%$ in oil concentration (Rotundo and Westgate, 2009).
The oil concentration followed an opposite trend to that of the protein concentration; it decreased when the protein concentration increased in each of the three studied cultivars (Table 1); this result is consistent with the findings of Chung et al. (2003) who concluded that as a general rule, soybean seed protein concentration is negatively correlated with the concentration of seed oil.

\section{CONCLUSIONS}

Based on the results, it could be concluded that drought stress has different influences on soybean cultivars belonging to the same maturity group in the current climatic conditions in Debrecen; it noticeably decreased the yield, protein and oil concentrations of certain cultivars whereas significantly increased them for others. The explanation for these results is the cultivar itself and its adaptation to this abiotic stress on 
one hand, and the timing of stress application on the other. This research should be extended to other spots across Hungary to evaluate the probable effects of drought stress on soybean traits. In addition, it will be useful to engage other soybean cultivars from other maturity groups and to apply drought stress at different stages of soybean's vegetation period in order to come out with an overall estimation convenient to the different climatic conditions across Hungary.

\section{REFERENCES}

Allen, D. K.-Ohlrogge, J. B.-Shachar-Hill, Y. (2009): The Role of Light in Soybean Seed Filling Metabolism. The Plant Journal 58, 220-234.

Avila, A. M. H.-Farias, J. R. B.-Pinto, H. S.-Pilau, F. G. (2013) Climatic restrictions for maximizing soybean yields. In: Board, J.E. (Ed.), A Comprehensive Survey of International Soybean Research-Genetics, Physiology, Agronomy and Nitrogen Relationships. InTech. Climatic Restrictions for Maximizing Soybean Yields. Intech press, 367-375.

Bellaloui, N.-Mengistu, A. (2008): Seed composition is influenced by irrigation regimes and cultivar differences in soybean. Irrig Sci. 26, 261-268.

Boydak, E.-Alpaslan, M.-Hayta, M.-Gercek, S.-Simsek, M. (2002): Seed composition of soybeans grown in the Harran region of Turkey as affected by row spacing and irrigation. J Agric Food Chem. 50, 4718-4720.

Chalk, P. M.-Alves, B. J. R.-Boddey, R. M.-Urquiaga, S. (2010) Integrated effects of abiotic stresses on inoculant performance, legume growth and symbiotic dependence estimated by $15 \mathrm{~N}$ dilution. Plant Soil 328, 1-16.

Chung, J.-Babka, H. L.-Graef, G. L.-Staswick, P. E.-Lee, D. J.Cregan, P. B.-Shoemaker, R. C.-Specht, J. E. (2003): The seed protein, oil, and yield QTL on soybean linkage group I. Crop Science, 43(3), 1053-1067.

De Paola, F.-Giugni, M.-Topa, M. E.-Bucchignani, E. (2014): Intensity-Duration-Frequency (IDF) rainfall curves, for data series and climate projection in African cities. SpringerPlus 3, 133.

Fang, X. W.-Turner, N. C.-Yan, G. J.-Li, F. M.-Siddique, K. H. M. (2010): Flower numbers pod production, pollen viability, and pistil function are reduced and flower and pod abortion increased in chickpea (Cicer arietinum L.) under terminal drought. J. Exp. Bot. 61, 335-345.

Fehr, W. R.-Hoeck, J. A.-Johnson, S. L.-Murphy, P. A.-Nott, J. D.Padilla, G. I.-Welke, G. A. (2003): Genotype and Environment Influence on Protein Components of Soybean. Crop Science 43, 511-514.

Gao, J.-Hao, X.-Thelen, K. D.-Robertson, G. P. (2009): Agronomic management system and precipitation effects on soybean oil and fatty acid profiles. Crop Sci. 49, 1049-1057.

Kato, Y.-Kamoshita, A.-Yamagishi, J. (2008): Preflowering abortion reduces spikelet number in Upland rice (Oryza sativa L.) under water stress. Crop Sci 48, 2389-2395.

Khan, M. N.-Komatsu, S. (2016): Proteomic analysis of soybean root including hypocotyl during recovery from drought stress. Journal of Proteomics 144, 39-50.

Ku, Y. S.-Au-Yeung, W. K.-Yung, Y. L.-Li, M. W.-Wen, C. Q.Liu, X.-Lam, H. M. (2013): Drought stress and tolerance in soybean. In: Board, J.E. (Ed.), A Comprehensive Survey of International Soybean Research - Genetics, Physiology, Agronomy and Nitrogen Relationships. InTech, Rijeka, 209237.
Leport, L.-Turner, N. C.-Davies, S. L.-Siddique, K. H. M. (2006): Variation in pod production and abortion among chickpea cultivars under terminal drought. Eur. J. Agron. 24, 236-246.

Li, D.-Liu, H.-Qiao, Y.-Wang, Y.-Cai, Z.-Dong, B.-Shi, Ch.-Liu, Y.-Li, X.-Liu, M. (2013): Effects of elevated $\mathrm{CO}_{2}$ on the growth, seed yield, and water use efficiency of soybean (Glycine $\max ($ L.) Merr.) under drought stress. Agricultural Water Management 129, 105-112.

Merah, O. (2001): Potential importance of water status traits for durum wheat improvement under Mediterranean conditions. J. Agric. Sci. 137, 139-145.

Mittler, R.-Blumwald, E. (2010): Genetic engineering for modern agriculture: challenges and perspectives. Annu. Rev. Plant Biol. $61,443-462$.

Morison, J. I. L.-Baker, N. R.-Mullineaux, P. M.-Davies, W. J. (2008): Improving water use in crop production. Philos. Trans. R. Soc. Biol. Sci. 363, 639-658.

Mutava, R. N.-Prince, S. J. K.-Syed, N. H.-Song, L.-Valliyodan, B.-Chen, W.-Nguyen, H. T. (2015): Understanding abiotic stress tolerance mechanisms in soybean: A comparative evaluation of soybean response to drought and flooding stress. Plant Physiology and Biochemistry 86, 109-120.

Reynolds, M.-Tuberosa, R. (2008): Translational research impacting on crop productivity in drought-prone environments, Curr. Opin. Plant Biol. 11, 171-179.

Rosenzweig, C.-Tubiello, F. N. (2007): Adaptation and mitigation strategies in agriculture: an analysis of potential synergies. Mitig. Adapt. Strateg. Glob. Chang. 12, 855-873.

Rotundo, J. L.-Westgate, M. E. (2009): Meta-analysis of environmental effects on soybean seed composition. Field Crop Res. 110, 147-156.

Song, Y. S. (1986): Peroxidase activities in relation to drought resistance. Heilongjiang Agric. Sci. 1, 41-44 (in Chinese).

Turner, N. C.-Davies, S. L.-Plummer, J. A.-Siddique, K. H. M. (2005): Seed Filling in Grain Legumes under Water Deficits, with Emphasis on Chickpeas. Advances in Agronomy 87, 211-250.

Valliyodan, B.-Nguyen, H. T. (2006): Understanding regulatory networks and engineering for enhanced drought tolerance in plants, Curr. Opin. Plant Biol. 9, 189-195.

Vurukonda, S. Sh. K. P.-Vardharajula, S.-Shrivastava, M.-SkZ, A. (2016): Enhancement of drought stress tolerance in crops by plant growth promoting rhizobacteria. Microbiological Research 184, 13-24.

Wilson, R. F. (2004): Seed composition. In: HR Boerma, JE Specht (eds) Soybeans: improvement, production, and uses. ASA, Madison, 621-677.

Xie, F. D.-Dong, Z.-Sun, Y. H.-Wang, X. G. (1994): Influence of drought on growth and yield of soybeans at different growth stages. J. Shenyang Agric. Univ. 25 (1), 13-16 (in Chinese).

Yamaguchi-Shinozaki, K.-Shinozaki, K. (2006): Transcriptional regulatory networks in cellular responses and tolerance to dehydration and cold stresses. Annu. Rev. Plant Biol.57, 781803. 